\title{
The Study of the Human Remains from Nubia: The Contribution of Grafton Elliot Smith and his Colleagues to Palaeopathology
}

\author{
H A WALDRON*
}

Human remains have excited the curiosity and interest of the general public for centuries but their systematic study, and that of the diseases whose marks they bear, has been erratic and most often a fringe activity of those whose professional interests were directed mainly elsewhere. The first palaeopathological report appears to have been that of Esper ${ }^{1}$ who described a tumour in the femur of a cave bear but which Mayer subsequently considered to be a simple fracture. ${ }^{2}$ Other reports in the eighteenth and early nineteenth centuries were also concerned with fossilized animal bones and credit for the introduction of human palaeopathology is generally accorded to Virchow in consideration of his publication on Neanderthal bones in $1872 .{ }^{3}$ Virchow described a shortening of the ulna and humerus which he thought was due to rickets and osteoarthritis (arthritis deformans); the diagnosis of rickets was substantiated much later by Ivanhoe. ${ }^{4}$

Palaeopathological studies in Europe lagged far behind those in America, however, where J C Warren and S G Morton had produced works on the crania of the mound builders between 1822 and 1839 and begun what Jarcho described as a cranial fixation which persisted well into the first half of the twentieth century. ${ }^{5}$ Both Warren and Morton described artificial cranial deformation and, in Morton's case, evidence for trauma. The first systematic study of disease in ancient human remains in America was undertaken by Joseph Jones, the results of which were published in a monograph in $1876 .{ }^{6}$ Syphilis was one of the diseases which Jones reported as being present in his assemblage and this disease became a subject of intense speculation among early American palaeopathologists.

The studies in America had been stimulated very largely by the great quantities

* H A Waldron, PhD, Institute of Archaeology, University College London, London WC1H OPY.

\footnotetext{
${ }^{1}$ E J C Esper, Ausführliche Nachrichten von neurentdeckten Zoolithen unbekannter vierfüssige Thiere, Nuremberg, 1774.

${ }^{2}$ F J C Mayer, 'Über krankhafte Knochen vorweltliche Thiere', Nova Acta Leopoldina, 1854, 24: 673-89.

${ }^{3}$ R Virchow, 'Untersuchung des Neanderthal Schädels', Zeitschrift für Ethnologie, Berlin, 1872, 4: 57-65.

${ }^{4} \mathrm{~F}$ Ivanhoe, 'Was Virchow right about Neandertal?', Nature, 1970, 227: 577-9.
}

\footnotetext{
${ }^{5}$ Warren's observations were published in his Comparative view of the sensorial and nervous systems in man and animals (Boston, Ingraham, 1822) as an appendix entitled 'Account of the crania of some of the aborigines of the United States' (pp. 129-44). Morton's findings were contained in his Crania Americana, Philadelphia, Dobson, 1839. See also S Jarcho (ed.), Human palaeopathology, New Haven, Yale University Press, 1966, p. 5.

${ }^{6} \mathrm{~J}$ Jones, Explanations of the aboriginal remains in Tennessee, Washington, Smithsonian Institution, 1876.
} 


\section{H A Waldron}

of Indian remains discovered during the push west in the early years of the nineteenth century. Nothing similar had been found in the Old World until the excavations which started in advance of the raising of the Aswan Dam in 1907. In that year, the Egyptian Government proposed to increase the height of the dam by seven metres to enhance the volume of water stored upstream. The dam had originally been constructed in 1902 in order to improve the irrigation of the cotton crop in Lower and Middle Egypt, but when it was completed many archaeological sites were submerged and the famous temple at Philae had been inundated. The effect of raising the dam further would be to bring another large tract of land under water with the inevitable consequence that many more archaeological sites, including many cemeteries, would be lost. It was decided that they should be rescued in advance of the flooding and the Egyptian Government set aside a considerable sum of money to permit the work to go ahead. The excavations were to be carried out under the direction of George Reisner (1867-1942) and it was hoped that a study of the human remains which would be recovered would not only enable the culture of the people who had once inhabited the valley to be reconstructed, but also their race and ethnological affinities. "Fortunately," wrote H G Lyons, who was overall director of the project, "the Egyptian Government had in its service one who was exceptionally fitted to undertake this portion of the work, Professor G. Elliot Smith, F.R.S., of the School of Medicine at Cairo".

The excavations also presented the opportunity for studying the occurrence of disease in the ancient Egyptians, and the work which was undertaken by Elliot Smith and his colleagues has been described by one authority as having changed the course of palaeopathology. ${ }^{8}$ This paper will discuss the extent to which the claim is justified.

\section{Before Egypt}

Elliot Smith was born in Grafton, New South Wales, on 14 August 1871. ${ }^{9}$ In 1888 he entered the new medical school in Sydney against the wishes of his father, who had wanted him to go into the insurance business. From his very earliest days he was interested in the brain, having attended an evening class in physiology before he entered medical school given by the then Dean of the Faculty of Medicine, Anderson Stuart. On one occasion the class was taken to the medical school and shown, and allowed to handle, human brains. Elliot Smith recalled that Anderson

\footnotetext{
${ }^{7} \mathrm{H}$ G Lyons, Preface, The archaeological survey of Nubia. Report for 1907-8, Volume I: Archaeological report, Cairo, National Printing Department, 1910, p. iv.

${ }^{8} \mathrm{G} \mathrm{J}$ Armelagos and J O Mills,

'Palaeopathology as science: the contribution of Egyptology', in W V Davies and R Walker (eds), Biological anthropology and the study of ancient Egypt, London, British Museum Press, 1993, p. 3.

${ }^{9}$ There are a number of sources for Elliot Smith's life. The most important is W R Dawson (ed.), Sir Grafton Elliot Smith, London, Jonathan Cape, 1938. Other useful sources include Lord
}

\author{
Zuckerman (ed.), The concepts of human \\ evolution, London, Academic Press for the \\ Zoological Society of London, 1973; A P Elkin \\ and N W G Macintosh (eds), Grafton Elliot \\ Smith: the man and his work, Sydney University \\ Press, 1974; A A Abbie, 'Sir Grafton Elliot \\ Smith', Bulletin of the Post-Graduate Committee \\ in Medicine, University of Sydney, 1959, 15: \\ 101-50. There are many obituaries, including an \\ interesting one by F Wood Jones, 'Grafton Elliot \\ Smith: life and work of a famous Australian', \\ The Australian National Review, 1937, 1 (4): \\ 2-8.
}




\section{The Study of Human Remains from Nubia}

Stuart pointed out the convolutions of the brain to the class and told the assembled students that no one knew them all; "I remember silently framing the vow that I should be the one exception to this statement," he wrote in the brief fragment of autobiography he completed shortly before his death in $1937 .{ }^{10}$ In his first year at medical school Elliot Smith won the prize for natural history and chose David Ferrier's Localization of the brain, and he was taught how to use Weigert's stain to demonstrate the myelinated fibres in the spinal cord by Almroth Wright. He quickly came to the attention of $\mathrm{J} \mathrm{T}$ Wilson, the professor of anatomy who made him a prosector in the department after he had completed his year as a house surgeon." As he had a "craving for original research in neurology" 12 he chose to undertake some neuroanatomical work. He was dissuaded from studying the nervous system of the cat and choose to study marsupials instead, since these animals were available to relatively few anatomists, and the anatomy and histology of the cerebrum of marsupials became the topic of his MD thesis awarded in 1895.

The conditions in Australia could not satisfy someone so ambitious as Elliot Smith, however, and having been awarded a two-year travelling scholarship by the University of Sydney, he set sail for London in the RMS Himalaya on 11 April 1896, with letters of introduction from Wilson to many of the most prominent anatomists in Great Britain. He arrived in England in June and settled in rooms in Montague Street, just off Russell Square and began his round of visits. One of the first anatomists he met was Arthur Keith (1866-1955), who was then working at the London Hospital. They were guests together at dinner and Keith noted the meeting in his diary (14 June 1896):

Met Elliot Smith just arrived from Sydney. Aet 24; earnest in his work, quiet, scientifically one-sided; anatomy evidently his one interest. Will be a big anatomist but not a big man. So reticent, giving no local colour of his life. He missed the last train; walked home with me but knew him and his work no better. Slept overnight at No. 17 [Bernard Street]. ${ }^{13}$

Others whom Elliot Smith met in his early days in London included G B Howes, the professor of zoology at the Royal College of Science in South Kensington. Howes gave Elliot Smith facilities for work and was instrumental in getting some of his early papers published. He was also introduced to Alexander Macalister, the professor of anatomy at Cambridge, who persuaded him to enter St John's College as a research student. Elliot Smith wrote to Wilson, "Macalister ... seems ... to be intensely devoted to Anthropology of, I am sorry to say, the bone-measuring variety." ${ }^{14}$ Elliot Smith entered St John's, in November 1896 and continued his neuroanatomical researches. When his travelling studentship ran out he was awarded

${ }^{10} \mathrm{G}$ Elliot Smith, 'Fragments of autobiography', in Dawson (ed.), op. cit., note 9 above, pp. 113-20, on p. 115 .

${ }^{11}$ Elliot Smith was Wilson's most famous pupil and although they remained firm friends for life, Elliot Smith was not always overly impressed with his teacher. In particular, he thought that Wilson's lectures on osteology were so boring that they "rapidly killed all interest in the subject":
P Morison, $J T$ Wilson and the fraternity of

Duckmaloi, Amsterdam, Rodopi, 1997, p. 99.

${ }^{12}$ Dawson (ed.), op. cit., note 9 above, p. 118.

${ }^{13}$ A Keith, An autobiography, London, Watts, 1950 , p. 201.

${ }^{14} 7$ September 1896; in Dawson (ed.), op. cit., note 9 above, p. 21. This was a somewhat ironic remark in view of Elliot Smith's own later career. 


\section{H A Waldron}

an annual scholarship of $£ 150$ by the British Medical Association and in 1899 he was elected a Fellow of St John's, which secured him financially. In 1899 he was invited by the Royal College of Surgeons (RCS) to catalogue their collection of brains and the catalogue was published three years later. This was the most substantial of his early works and was generally accepted as a tour de force which considerably enhanced his growing reputation.

In 1900, Macalister, who had an interest in Egyptology and who had spent the previous winter in Cairo visiting the medical school, wrote to Elliot Smith to ask if he would be willing to take the chair of anatomy there. Elliot Smith quickly accepted the offer and arrived in Cairo in October, having married in London and honeymooned in Paris en route. "I have now quite resisted the temptation to dabble in Egyptology", he wrote to Wilson in February the following year. ${ }^{15}$ His resolve was short lasting, however, for by November he was writing to Wilson again, this time to tell him that he had begun his study of the remains of "the Early Egyptian people"16 and then, as A J E Cave wrote, ${ }^{17}$ "Egypt's spell ensnared him to his own lifelong enthralment ...".

Elliot Smith's interest in anthropology was apparently aroused by W H R Rivers (1864-1922), who had been a colleague at St John's and who was visiting Egypt to study colour blindness in the local population. Rivers camped with some of the archaeologists in Upper Egypt, using their workmen as subjects for his study. He wrote to Elliot Smith shortly after his arrival to tell him that a number of the skulls being uncovered contained well-preserved brains and Elliot Smith went at once to see for himself. "In the first Egyptian grave that I looked into I saw the skeleton of an Egyptian boy, in whose pelvis there was a large vesical calculus. The interest of finding a stone in the bladder that was several millennia older than any other recorded case at once arrested my attention."18

Elliot Smith started to visit archaeological sites and took the opportunity to examine remains from the graves which were being uncovered by the Hearst Expedition under the direction of Reisner, whose recollection was that

Dr G Elliot Smith ... wished to obtain osteological and other material for researches on the racial characteristics, the diseases, and the treatment of bodies for burial of the ancient Egyptians. I immediately offered him all our material, which at that time, owing to the condition of the bodies in Cemetery 7000, was particularly interesting. ${ }^{19}$

Elliot Smith's account is somewhat at variance with this, however. He maintained that it was Reisner who invited him to examine the material because someone was needed to determine the age, sex and the diseases affecting the bodies being unearthed at the site. ${ }^{20}$

Elliot Smith went on holiday to Australia in the summer of 1902 and when he

${ }^{15}$ Dawson (ed.), op. cit., note 9 above, p. 32.

${ }^{16}$ Dawson (ed.), op. cit., note 9 above, p. 33.

${ }^{17}$ A J E Cave, 'A master anatomist', in Dawson (ed.), op. cit., note 9 above, p. 195.

${ }^{18} \mathrm{G}$ Elliot Smith, 'The diversions of an anatomist in Egypt', Cambridge University Medical School Magazine, 1926, 5: 34-9.
${ }^{19} \mathrm{G}$ A Reisner, The early dynastic cemeteries of Naga-ed-Dêr, Part I. University of California Publications on Egyptian Archaeology, Leipzig, J C Hinrichs, 1908, p. vii.

${ }^{20}$ Elliot Smith, op. cit., note 18 above, p. 35. 
returned to Cairo in September he found sixty-four crates of human remains waiting for his attention. "For the past five weeks I had literally not a moment to call my own", he wrote to Robert Broom in Sydney. ${ }^{21}$ Nevertheless, the following spring found him once again in the field, with a thousand more skeletons to examine and "for the next six months I expect to be a slave to anthropology". ${ }^{22}$

The following year, Elliot Smith began his study of mummies. He made the first ever radiographic examination of a mummy, that of Thutmosis IV, which was taken by cab to a private nursing home in Cairo, then the only medical establishment with an x-ray apparatus. ${ }^{23} \mathrm{He}$ was later to examine all the royal mummies in the Cairo Museum and published a monograph detailing his findings, and a book on embalming procedures with Warren Dawson. ${ }^{24}$

\section{In Nubia}

Elliot Smith was drawn into the work in Nubia because of his interest in the possibility of determining race from the examination of skeletal remains: "in Nubia the significance of the question of race as an adjunct to the archaeological study becomes enormously enhanced by the fact that it is certainly the determining cause of the modifications of culture revealed in the graves so far examined." ${ }^{25}$ Elliot Smith went to Shellal to see how work was progressing in October 1907 and found that more than two thousand bodies had already been uncovered and that each day many more were being added to this number. There was "far more material than it was possible to investigate, even if I had been able to devote the whole of my time to the task". ${ }^{26}$ Accordingly he sent a cable to Frederic Wood Jones asking if he would come out to help him. Wood Jones left at once and was camped in Nubia by the last week in October. ${ }^{27}$

Wood Jones was born on 23 January 1879 in Hackney, in the East End of London. His father was a builder and, as he prospered, the family moved to Enfield where Wood Jones went to school before entering the London Hospital Medical College in 1897. At the London Hospital be came to know Arthur Keith, who became his lifelong friend and mentor. Before he formally began his medical studies, he heard a lecture given by Keith. Much later, writing to commiserate with Keith over the death of his wife, Wood Jones wrote: "it was in 1897 when first I was your student and you made me love anatomy because I loved my teacher ... although I have annoyed you time and again ... I have always tried to carry on the ideals of anatomy I learned from you." ${ }^{28}$ Keith returned Wood Jones's affection-of his students, he

${ }^{21} 5$ November 1902, in Dawson (ed.), op. cit., note 9 above, p. 36.

${ }_{22}$ To Broom, 2 March 1903, in Dawson (ed.), op. cit., note 9 above, p. 36. $38-9$.

${ }^{23}$ Dawson (ed.), op. cit., note 9 above, pp.

${ }^{24} \mathrm{G}$ Elliot Smith, The royal mummies, Cairo, L'Institut français d'archéologie orientale, 1912; G Elliot Smith and W R Dawson, Egyptian mummies, London, George Allen \& Unwin, 1924.

${ }^{25} \mathrm{G}$ Elliot Smith and $\mathrm{F}$ Wood Jones, The archaeological survey of Nubia 1907-1908. Volume
2. Report on the human remains, Cairo, National

Printing Department, 1910, p. 7.

${ }^{26}$ Elliot Smith, op. cit., note 18 above, p. 8.

${ }^{27} \mathrm{~F}$ Wood Jones, 'In Egypt and Nubia', in

Dawson (ed.), op. cit., note 9 above, p. 142. ${ }^{28} 22$ November 1934. Letter in the Royal College of Surgeons of London Library. Letters from this collection will be referred to as RCS hereafter. 


\section{H A Waldron}

wrote, "In the first place, Frederic Wood Jones. He was the most gifted of the men whom I met among the students of the London Hospital." 29 Wood Jones graduated in 1904, having been for the latter part of that year a demonstrator in Keith's department. It might have been thought that Keith would have been anxious to keep his young protégé working with him but, instead, he advised him to take a post as medical officer for the Eastern Extension Telegraph Company in their outpost on the Cocos-Keeling Islands thinking that it might benefit him in much the same way that tropical voyages had benefited Darwin and Huxley. Wood Jones went to the Cocos-Keeling Islands by way of Singapore. He studied the flora and fauna of the islands and the formation of the coral reefs. He also met the married daughter of the Governor, Gertrude Blom, whom he married in 1922 after her divorce. ${ }^{30}$

Wood Jones returned to London in March 1907 and took up the position as demonstrator in anatomy at the London Hospital and was working there with Keith when Elliot Smith's cable reached him.

Elliot Smith and Wood Jones embarked on a project which has been described by Armelagos and Mills as changing the course of palaeopathology. ${ }^{31}$ The excavations in Nubia were conducted over four seasons, 1907-1911. Reisner directed the excavation during the first (1907-1908), and thereafter the dig was directed by C M Firth. Conditions in the desert were very arduous. They had decided before they went into the field which measurements they would take and Elliot Smith had cards printed on which to enter the details, the cards being blue in colour "To protect the eyesight from the glare of the sun [on them]" ${ }^{32}$ Wood Jones described their method of working as follows:

He sat at one end of the grave and I at the other. The heat was terrific; the metal callipers became too hot to hold with comfort unless care was taken to place them in what little shade was thrown by one's own body. The flies were legion, they swarmed about our faces and crept into our eyes. Every now and again a hot swirl of dust, of very evil origin, would come circling across the dry mud plain and over the grave where we sat.

Elliot Smith's voice was peculiarly deep and level ... a maddening one when employed in the monotonous recitation of endless measurements and figures. I brushed the dust and the flies from my face and wrote, seeming without end, "minimum frontal breadth ninety-one,

${ }^{29}$ Keith, op. cit., note 13 above, p. 273.

${ }^{30}$ B E Christophers, 'Frederic Wood Jones: corals and atolls', Australian and New Zealand Journal of Surgery, 1995, 65: 749-60.

Christophers suggests that one reason why Wood Jones accepted Elliot Smith's invitation to Nubia was to distance himself from Gertrude who had returned to London shortly after Wood Jones himself left the islands. Christophers is the foremost authority on Wood Jones and has written much on various aspects of his life. See idem, 'Frederic Wood Jones', Medical Journal of Australia, 1972, 42: 325-9; 'Frederic Wood Jones, artist and illustrator', ibid., 1992, 62: 60-9; 'Frederic Wood Jones' empathy with living creatures', ibid., 1993, 63: 299-306; 'Frederic Wood Jones at school and university', ibid., 1994,
64: 27-37; 'Frederic Wood Jones: his academic medals and those they honoured', ibid., 1995, 65: 122-34; A list of the published works of Frederic Wood Jones 1879-1954, Melbourne, Greensborough Press, 1974. Other useful sources include: W E le Gros Clark, 'Frederic Wood Jones', Biographical Memoirs of Fellows of the Royal Society, 1955, 1: 119-34; J Guest, John Hunter's disciple: Frederic Wood Jones. Vicary Lecture 1989, London, Royal College of Surgeons, n.d.; C Wakeley, 'Frederic Wood Jones and the Hunterian tradition', Annals of the Royal College of Surgeons of London, 1964, 34: 359-69.

${ }^{31}$ Armelagos and Mills, op. cit., note 8 above, p. 3.

${ }^{32}$ Elliot Smith, op. cit., note 18 above, p. 10. 


\section{The Study of Human Remains from Nubia}

bizygomatic breadth one thirty-seven, cranial breadth ..." At intervals I would look at my entirely serene ... chief and wondered how much longer I could stand it ... and then, throwing the hot callipers into the sand, he gave his opinion of the flies, the dust, the heat, the village of Shellal and the ancient dead in one comprehensive and highly descriptive sentence that must have come straight from the remembered repertoire of his student days in Sydney. ${ }^{33}$

Elliot Smith had to return to Cairo in November to get to grips with running his department again. He wrote to Keith, expressing his thanks for sending Wood Jones to him.

I have been intending to write to you for some weeks to thank you for letting me have Wood Jones. As you say with perfect truth "I have far too much in hand" ... [and] my only consolation is the thought "what a mess there would have been in Nubia if I had not had Wood Jones!" For I know of no other man who could have tackled the stupendous tasks there as he has done. ${ }^{34}$

Meanwhile Wood Jones continued alone, evidently becoming frustrated with the work. One of the objectives which he and Elliot Smith had chosen was to test the various methods of sexing the skeletons, "the sex of which was evident". ${ }^{35} \mathrm{He}$ found himself running foul of Reisner, however.

I have not seen Elliot Smith since Dec $10^{\text {th }} \&$ don't know when he will return the wrote to Keith] ... at every turn I run counter to the archaeologist and his most cherished hopes. He calls mummies $\delta$ from various designs on the covering. He has a sign that he says represents a beard-I open it \& find a $q$ within. Yesterday I broached a mummy with a "beard" \& found portions of $1 \%$ and $2 \delta$ skeletons!! The archaeologists would have me understand that I am a fool and a liar. They tell me the burial was disturbed. I say it was intact. They say I have misread the bones. I tell them (what is true) that $I$ have got them all sealed in a box $\&$ if they doubt it they have to break the seals that I put on. ${ }^{36}$

There was a little good news, however, for "I am to have a clerk to keep my notes \& so I shall soon get more time in which to do real work-work apart from callipers". ${ }^{37}$ Despite this, Wood Jones was clearly not happy and intimated to Elliot Smith that he would not stay in Egypt beyond the following May. Elliot Smith wrote to Keith to tell him this, but also to ask whether Keith had any other bright young men to send in his place.

Wood Jones has done a lot of work in Nubia, and he has relieved me of a lot of trouble. Hence his decision to quit work in Egypt in May comes as a great blow, although I expected it and in his place would have done the same ... We shall want a man next October to take on the work W.J. is doing now: so I hope you will keep your eyes open for someone. I cannot hope for anyone to do what Wood Jones has done, but you may possible [sic] know of some hard-working young man ... who would take on the job. ${ }^{38}$

In February, Wood Jones was still grumbling about "the Reisner man" but was otherwise in a more optimistic mood.

\footnotetext{
${ }^{33}$ Wood Jones, op. cit., note 27 above, p. 143.

${ }^{34}$ RCS 3 December 1907.

${ }^{35}$ Wood Jones, op. cit., note 27 above, p. 144.
}

${ }^{36}$ RCS 1 January 1908.

${ }^{37}$ Ibid.

${ }^{38}$ RCS 27 December 1907. 


\section{H A Waldron}

... it is wonderful how things turn out. I got back here-we are about 20 miles south of Shellal-at nearly two o'clock and by five I have found (1) the only case of septic bone disease that has turned up (2) the earliest case of genuine tuberculosis I suppose (3) a wonderful fracture of pelvis healed (4) 2 fractured femora and a fractured ulna-all this is in the run of the afternoon's routine anatomy.

I do not envy you your collection in Lincoln's Inn.-I wonder if you have on your shelves an infant's head with all the sutures of the vault-even one squamous-closed! I have one in my bed room. And yesterday I came on another of closure before the eruption of $\mathrm{m}^{3}$-which takes place early in these folk. I have a wonderful collection of fractures.

I shant [sic] see Elliot Smith till next month. I am afraid that he has not been here since Jan $11^{\text {th }}$. He has too much work in Cairo. ${ }^{39}$

Wood Jones continued to work on alone and he was anxious for Elliot Smith to rejoin him.

Elliot Smith has been most generous to me all through this expedition. Thank Heavens soon he will be down with us again-I have not seen him since January. I have definitely applied to come home on May $1 . .$.

I am having a very troublous time here in one way or another. Sick people \& anthropologists are continuing to keep me anxious all the time. But I shall buck up again. ${ }^{40}$

At the end of March, Wood Jones joined Elliot Smith in Cairo and worked with him there until his return to London. "I am handing over the whole of the pathological side of our annual report to W.J.", wrote Elliot Smith to Arthur Keith, and "I have suggested that a large collection of the Nubian pathological specimens be presented to the R.C.S. Museum: Wood Jones could then compare our material with yours and get all the advice and help he needs from your people to enable him to write a really good report."41 Arthur Keith did not have a replacement for Wood Jones, instead Elliot Smith replaced him with one of his own staff at the medical school in Cairo, Douglas Derry (1874-1961).

Derry had studied medicine in Edinburgh, graduating in 1903. He worked in Edinburgh in the department of anatomy before becoming assistant professor in Elliot Smith's department in Cairo in 1905. He took over the anthropological work of the Nubian survey from Wood Jones in 1909 but stayed for only one year before returning to England himself, to work in the department of anatomy at University College, London. ${ }^{42}$

Derry had actually been involved in some of the work on the Nubian material before Wood Jones's arrival, however. Almost as soon as he arrived in Cairo he found that Elliot Smith:

had already begun a systematic examination and measurement of the human remains in the cemetery [Reisner's 4th and 5th necropolis], and together we accumulated a large number of

$$
\text { Keith. }
$$

${ }^{39}$ RCS 18 February 1908, Wood Jones to

${ }^{40}$ RCS 1 March 1908, Wood Jones to Keith.

${ }^{41}$ RCS 28 March 1908.

${ }^{42}$ U Fielding, 'Douglas Erith Derry', J. Anat., 1961, 95: 441-2; R H O B Robinson and W R Le Fanu, 'Derry, Douglas Erith', in Lives of the Fellows of the Royal College of Surgeons of England 1952-1964, Edinburgh, E \& S Livingstone, 1970. His obituary in the British Medical Journal (1961, i: 832-3) refers to "an interesting account of his work during the Nubian survey" but I have failed to locate it. 


\section{The Study of Human Remains from Nubia}

measurements to which I added many more during the following summer when, by $\mathrm{Dr}$ Reisner's invitation, I stayed at his camp and measured in the field and these data were to become of inestimable racial value later. ${ }^{43}$

\section{Derry continued working:}

In the following year [1906] as I did not go home in the summer vacation, I stayed with Dr Reisner. As it was necessary to have an anatomist on the spot, Dr Wood Jones ... was brought out from England to carry out the anatomical and where necessary, pathological examination of the human remains during the first Season's work. In the subsequent years I was appointed to do the same. ${ }^{44}$

It might appear surprising at first sight that Derry was not immediately drafted in to undertake the work on the Nubian material. It is clear from his own account that he was involved in anthropology of the "bone-measuring variety" and, as will be shown later, Elliot Smith never took more than a passing interest in palaeopathology even though he did later lay claim to having started Marc Armand Ruffer on his studies. ${ }^{45}$ Elliot Smith might then have considered that Derry's work of measuring skeletons was too important to be sacrificed for the Nubian material. On the other hand, it may simply have been the intense pressure of work; in 1913,

\footnotetext{
${ }^{43}$ Derry papers held in the Institute of Archaeology, University College London library. The archive contains a 61 page notebook, manuscripts of papers, reprints of papers, letters from various correspondents and a number of unpublished photographs. Hereafter referred to as IOA.

${ }^{44}$ IOA, Derry MS.

${ }^{45}$ In his review of Roy L Moodie's The antiquity of disease and of his edited edition of Ruffer's papers (Studies in the palaeopathology of Egypt) Elliot Smith referred to Moodie's account of the history of investigations into the pathology affecting the ancient Egyptians. Since Elliot Smith considered that Moodie's account was "quite fictitious" he thought he "had better explain how they did begin". According to Elliot Smith, Ruffer did not begin his work until Wood Jones and he had ended theirs. In 1908, Elliot Smith found a hunch-back among the mummies of the priests of Amun from Thebes and asked Ruffer if he could detect tubercle bacilli in the psoas abscess. "This started Sir Armand on the work". ('The antiquity of disease', Nature, 1923, 111: 875-6). In the same review, Elliot Smith objected to the "wholly unnecessary and ambiguous word "palaeopathology" "which Moodie and most others since have supposed was first used by Ruffer. In fact, R W Schufeldt used it almost twenty years earlier ('Notes on palaeopathology', Popular Science Monthly, 1893, 42: 679-84). The case of tuberculosis was written up and published jointly by Elliot Smith and Ruffer
}

(G Elliot Smith and M A Ruffer, 'Pott'sche Krankheit in einer ägyptischer Mumie, aus der Zeit der 21 Dynastie, um 1000 vor Chr', No. 3 of Sudhoff and Sticker's Historische Biologie der Krankheitserreger, Giessen, 1910). Ruffer is probably the most important figure in the early history of palaeopathology. He was born in Lyons in 1859 of a French father and a German mother. He was educated at Brasenose College, Oxford, and University College, London, where he qualified in medicine in 1887. His early work was as a bacteriologist and he worked with Pasteur and Metchnikoff at the Pasteur Institute before becoming the first director of the British Institute of Preventive Medicine in 1891. While working at the Institute he contracted diphtheria while testing a new diphtheritic serum and was so seriously affected that he resigned his directorship and went to Egypt to recuperate. In 1896 he was appointed professor of bacteriology at Cairo University and began his palaeopathological studies as described above. He was involved in a number of international ventures during the First World War and died when the ship on which he was travelling was torpedoed in 1917. Moodie contributed a brief autobiographical note and a bibliography to the volume of Ruffer's collected papers on palaeopathology (the first volume devoted entirely to the subject) and Sandison wrote an appreciation of him to mark the fiftieth anniversary of his death (A T Sandison, 'Sir Marc Armand Ruffer (1859-1917)', Med. Hist., 1967, 11: 150-6); a definitive biography has yet to appear. 


\section{H A Waldron}

Elliot Smith wrote a postcard to Derry from Manchester: "You know the conditions under which we worked in Cairo and how impossible it was to use all the material that wanted working up."46

\section{The Examination of the Human Remains}

The results of the examination of the Nubian material by Elliot Smith and his colleagues were contained in a series of Bulletins published between 1907 and 1910, and in a large report published in $1910 .^{47}$ Only a handful of separate papers were published in the medical press, something which would be unimaginable today, and this, again, suggests some indifference on the part of the three principals to the large amount of pathology they were finding.

The Bulletins ${ }^{48}$ generally had an introduction or an anatomical report by Elliot Smith and pathological or supplementary anatomical reports by either Wood Jones or Derry. The report on the first season's work was co-authored by Elliot Smith and Wood Jones and written substantially when both had returned to England. ${ }^{49}$ Wood Jones later recalled how Elliot Smith had come to stay with him at his house in Ealing so that the work might be completed.

In the first Bulletin, Elliot Smith outlined what he saw as the duties of an anatomist working with an archaeologist. The first duty was to provide information "of essential importance in the interpretation of many of the results of the archaeological investigation". This should include the age, sex, suggestions of affinities between different bodies which might indicate family likenesses or race, evidence of mutilations - and the example chosen was that of circumcision-and attempts at preservation and embalming. ${ }^{50}$ The second was purely anthropological and "that to which most time and attention is devoted", that is, the determination of racial characteristics. This was achieved by "a study of the form and proportions of the face, the shape of the head and the nature of the hair" and by taking large numbers of measurements of all the important bones and the skull. ${ }^{51}$ In the Report, Elliot Smith was even more emphatic about the primary role of the anthropological work. "... the interpretation of the nature and meaning of ... racial contrasts assumed a special importance, and the determination of how and when they arose thus became

\footnotetext{
${ }^{46} 19$ November 1913, IOA.

${ }^{47}$ After Derry left Egypt in 1909 anatomical work was deferred (during the third season) and all the human remains which were in good condition were packed and shipped to England. During the fourth (1910-1911) season, no anatomist was available for field work and the material was sent to Cairo where Elliot Smith studied some of it, at least, during a visit in 1911.

${ }^{48}$ The archaeological survey of Nubia. Bulletin No. 1, dealing with the work up to November 30 , 1907, Cairo, National Printing Department, 1908; Bulletin No. 2, dealing with the work from December 1, 1907 to March 31, 1908, Cairo, National Printing Department, 1908; Bulletin No.
}

\author{
3, dealing with the work from October 1 to \\ December 31, 1908, Cairo, National Printing \\ Department, 1909; Bulletin No. 4, dealing the \\ work from January 1 to March 31, 1909, Cairo, \\ National Printing Department, 1909; Bulletin No. \\ 5: Dealing with the work from November 1 to \\ December 31, 1909, Cairo, National Printing \\ Department, 1910; Bulletin No. 6: Dealing with \\ the work from January 1 to April 15, 1910, Cairo, \\ National Printing Department, 1910. \\ ${ }^{49}$ Report, op. cit., note 25 above. \\ ${ }^{50}$ Bulletin No. 1, note 48 above, p. 25. \\ ${ }^{51}$ Ibid, p. 26.
}




\section{The Study of Human Remains from Nubia}

the chief aim of this Survey". ${ }^{52}$ Continuing with his account of the anatomist's work in the first Bulletin, Elliot Smith noted that various anomalies uncovered during the course of the examination of the remains were recorded and lastly, "the study of the incidence of disease and injury forms a very important part of the field work, revealing, as it does, facts which are of the utmost interest and importance in the history of medicine and surgery". ${ }^{53}$ The contribution which they could make to this part of the study, however, was acknowledged as likely to be relatively slight. "As neither of us can claim any special knowledge of pathology," he wrote, "we have asked for a more liberal allowance of illustrative photographs for the special report, so as to make perfectly clear the exact nature of the material with which we have to deal". 54

It is clear from reading the Bulletins and the Report that they were in no sense meant to be complete; all were regarded as interim publications and the intention was to study selected items more fully, either in Cairo or in London, but this never occurred. Elliot Smith's personal contribution was limited almost exclusively to the anthropological work and he and his co-workers were tremendously constrained by pressures of time and the sheer volume of material which the energetic archaeologists were unearthing. Elliot Smith admitted as much when writing in the Report that he and Wood Jones were so busy that "anything approaching an adequate account of all the human remains brought to light ... [was] out of the question". 55

From the point of view of the palaeopathologist, all the accounts of the work carried out in Nubia are profoundly disappointing and so far from changing the course of palaeopathology, they enable us, at best, to establish a terminus a quo for some conditions. The reasons for this disappointment are twofold, diagnostic and epidemiological. From the diagnostic point of view, it is often difficult to decide which diseases are being referred to, while from the epidemiological standpoint, even when one can be reasonably certain to which disease the authors are referring, it is impossible to gain any real impression of the frequency with which it occurred among the ancient Egyptians.

With the constraints imposed upon them, the authors of the Bulletins and the Report made reference only to those diseases which they considered to be of particular importance (tuberculosis and gout, for example), or which they encountered so frequently that they could not be overlooked-osteoarthritis, for example, or in which they developed a particular interest, and this applied only to the study of fractures.

One of the difficulties in interpreting the material is that several conditions may be subsumed under one broad heading; by contrast, several synonyms may be used for the same condition. This is exemplified by the treatment of osteoarthritis. This disease is variously referred to as rheumatoid arthritis, osteoarthritis, arthritis deformans, spondylitis deformans and osteitis deformans, and it is certain from

\footnotetext{
${ }^{52}$ Report, note 25 above, p. 7.

${ }^{53}$ Bulletin No. 1 , note 48 above, p. 26. Strictly speaking, Elliot Smith meant prevalence, rather than incidence here.
}

${ }^{54}$ Bulletin No. 2 , note 48 above, p. 41.
${ }^{55}$ Report, note 25 above, p. 9. 
some of the descriptions that other conditions, including possibly ankylosing spondylitis and perhaps some forms of erosive arthropathy, are included under the general rubric. Although the majority —and perhaps the great majority-are likely to have been what we would nowadays refer to as osteoarthritis, some important information about the antiquity of some of the less common forms of joint disease has been irretrievably lost.

Osteoarthritis was obviously very common. Writing about a group of skeletons recovered from archaic graves under the streets of Shellal, Wood Jones noted that "scarcely a single adult in the group had escaped osteo-arthritic changes in the bones, the disease being usually limited to the lumbar region of the spine" ${ }^{56}$ In the second Bulletin he notes that it was "of immense distribution ... the most common manifestation is spondylitis deformans ... it may present as a mere lipping of the adjacent edges of individual vertebrae, or it may involve many separate vertebrae, and even ankylose whole series firmly together." ${ }^{.57}$ The majority of palaeopathologists would be very unlikely to diagnose osteoarthritis solely on finding marginal osteophytes on the vertebrae, nor would they expect osteoarthritis to cause spinal ankylosis; this would be much more likely to be the result of a sero-negative arthropathy or diffuse idiopathic skeletal hyperostosis (DISH), for example. Osteoarthritis was common in the hips of the ancient Egyptians but osteoarthritis of the knee was "somewhat less common than would be expected from its modern frequency" ${ }^{58}$ Wood Jones speculated on the aetiology of the disease stating that its causal factor was "essentially one of environment, and not race", the Nile being of special importance. The river "was the chief factor in their lives ... [and] it may be that this exposure, with the alternate wetting and drying, in a climate which may be of severe cold, or intense heat, has provoked ... this remarkable frequency of osteoarthritic changes in these people." 59

Among other diseases noted was a single case of gout ("so-called rheumatic gout" as it was referred to) with concretions of a white material around the first metatarsals, some tarsal bones, the distal ends of the tibiae and fibulae, the posterior surface of the patella and the patellar ligament. The white material was confirmed as being uric acid by Dr W A Schmidt. ${ }^{60}$ There were also references to a single case of leprosy, to cleft palate, mastoiditis, osteosarcoma of the left humerus, rectal and vaginal prolapses, and some deaths in childbirth. A curious form of pitting in the roof of the orbits was noted, most often found in the skulls of children and young women. Neither Elliot Smith nor Wood Jones had seen it before, nor did they know its cause, so they included a photograph of a specimen in the second Bulletin "in the

${ }^{56}$ Bulletin No. 1 , note 48 above, p. 37.

${ }^{57}$ Bulletin No. 2 , note 48 above, p. 58.

${ }^{58}$ Report, note 25 above, p. 275 . This observation is of interest in view of the fact that it has been suggested that osteoarthritis of the hip was more common than that of the knee prior to and including the medieval period whereas in the post-medieval period, and until the present day, the converse is the case (J Rogers and P Dieppe,
'Is tibiofemoral osteoarthritis in the knee joint a new disease?' Annals of the Rheumatic Diseases, 1994, 53: 612-13; T Waldron, 'Changes in the distribution of osteoarthritis over historical time', International Journal of Osteoarchaeology, 1995, 5: 385-9)

${ }^{59}$ Report, note 25 above, p. 274.

${ }^{60}$ Bulletin No. 1 , note 48 above, p. 32. 


\section{The Study of Human Remains from Nubia}

hope of obtaining some information ... regarding the meaning of this curious condition". ${ }^{61}$

Throughout the Bulletins there was frequent mention of the presence, or the absence, of tuberculosis. In the first Bulletin, Wood Jones described the mummy of a young woman who "presented a perfect picture of tuberculous disease of bone", ${ }^{62}$ presumably the case mentioned in his letter to Arthur Keith. The disease affected the left elbow, the hip, sacro-iliac joint and the lowest two lumbar vertebrae. In the second Bulletin, however, Wood Jones reported that A R Ferguson, the professor of pathology at Cairo, had not been convinced by this case and that, since Dr Charles Todd of the public health department had failed to detect tubercle bacilli in the lungs, the diagnosis had been discounted. In the Report, therefore, he stated that no cases of tuberculosis had been found during the time that he had been working on the material. In subsequent Bulletins, however, further cases were reported by Derry; a case of Pott's disease in a young man was described in the third and was reported in the fourth as having been confirmed by Ruffer. Further cases were mentioned in a female and in a nine-year-old child in the fifth Bulletin, confirmation of these by Fraser being reported in the sixth. ${ }^{63}$

If tuberculosis had undoubtedly been present in Egypt since the earliest times, Elliot Smith was anxious to assert that syphilis had not. There had been previous claims that Egyptian skeletons showed evidence of syphilis which Elliot Smith had vigorously rebutted. His suggestion was that the lesions which had been attributed to syphilis by Dr D M Fouquet and Professor Louis Lortet were, in fact, due to damage caused by beetles boring into the surface of the bones in contact with soil. ${ }^{64}$ Later, he was able categorically to state "that no trace whatever of any lesion even suggesting syphilitic affections of bones or teeth was revealed in Egypt before the Middle Ages". ${ }^{65}$

One other condition in which Elliot Smith took a particular interest was biparietal thinning of the skull, which was rare in Europe but common from the third to the nineteenth dynasties, especially among the aristocracy. Elliot Smith supposed that

${ }^{61}$ Bulletin No. 2 , note 48 above, p. 33 . The condition is nowadays known as cribra orbitalia but its meaning is still far from obvious. There is a widespread view that it is due to iron deficiency anaemia but there is no clinical evidence to give support to this supposition.

${ }^{62}$ Bulletin No. 1 , note 48 above, p. 35.

${ }^{63}$ Derry later wrote an account of the Nubian cases to which he added two more of his own ('Pott's disease in ancient Egypt', Medical Press and Circular, 1938, 197: 196-9). The diagnosis of tuberculosis in Egyptian mummies has recently been confirmed beyond doubt by the extraction and amplification of bacterial DNA using the polymerase chain reaction (A G Nerlich, C J Hass, A Zink, U Szeimes and H G Hagedorn, 'Molecular evidence for tuberculosis in an ancient Egyptian mummy', Lancet, 1997, 350: 1404.

\footnotetext{
${ }^{64} \mathrm{G}$ Elliot Smith, 'The alleged discovery of syphilis in prehistoric Egyptians', Lancet, 1907, ii: 1788-9; 'The alleged discovery of syphilis in prehistoric Egyptians', ibid, 1908, ii: 521-4; 'La prétendue découverte de la syphilis chez les Égyptiens préhistoriques', Bulletin de la Société d'Anthropologie de Lyon, 1910, 29: 76-86. Earlier, Flinders Petrie had suggested that the lesions found on the long bones from Nagada were the result of cannibalism (W M Flinders Petrie and $\mathbf{J}$ E Quibell, Naqada and Ballas, London, Bernard Quaritch, 1896). Elliot Smith vehemently refuted this suggestion, relying instead on his beetle explanation and this resulted in an unhappy feud with Petrie as explained later.

${ }^{65}$ Elliot Smith op. cit., note 18 above, p. 38.
} 


\section{H A Waldron}

it was caused by the continuous pressure from wearing "wigs of enormous proportions and of great weight". ${ }^{66}$

The Nubian documents would be extremely valuable if they allowed one to make an estimate of the frequency of some of the conditions noted by their authors, but unfortunately this is not possible since the relevant data were not published. Epidemiologically - as well as pathologically - the documents promise much but give little. The number of human remains recovered is given, cemetery by cemetery, in Wood Jones's chapter on fractures in the Report (see Table 1) but a relatively small number of these was thoroughly examined. This was partly due to the press of time, but also to the relatively poor state of preservation of many of the bodies. In the third Bulletin, for example, Elliot Smith notes that the two thousand graves "yielded only three hundred sets of bones in a state of preservation that permitted complete measurements to be made" ${ }^{67}$ Where the bodies were well preserved, time was too short to permit all to be examined and material was selected for further study elsewhere. For example, from Cemetery 5, "Every skull which seemed likely to bear the journey to Cairo was saved ... and all the skeletons in good condition were packed for further study". ${ }^{68}$ The state of preservation was the criterion which determined whether or not a skeleton was to be selected for further study and while this seems a sensible basis on which to choose material, it would certainly have introduced a bias into the results of any epidemiological study, had one been carried out and reported; there is no evidence that this, in fact, was done for the reason that all three men working on the material left Egypt before this could be achieved. ${ }^{69}$

Although we know from Wood Jones's account that osteoarthritis was common, we can gain no idea of how common since we have neither numerators nor denominators to help us with the calculation. And this is the same for all the other conditions which are mentioned throughout the Bulletins and the Report with one exception.

The investigation of fractures certainly occupied a considerable amount of the time spent in the field and the chapter on fractures in the Report was substantially longer than the chapter on general pathology. There are likely to have been a number of reasons for this. Firstly, because the presence of a fracture is easy to recognize, the non-specialist is able to feel confident about making the diagnosis. And secondly, it happened that there was considerable evidence of the way in which the Egyptians treated fractures and this added an extra interest to this particular topic. "The afterresults of injuries to bones in a people so ancient as those with which this Survey is

\footnotetext{
${ }^{66}$ 'The causation of the symmetrical thinning of the parietal bones in ancient Egyptians', $J$. Anat. Physiol., 1907, 41: 232-3. When, much later, Elliot Smith examined a female skeleton from a neolithic barrow in Dunstable, he suggested that because of this, she must have been "accustomed to wear either a wig or some other heavy type of headgear": 'Report of the human remains found in No. 5 barrow at Dunstable', Man, 1927, 27: 25-7.

${ }^{67}$ Bulletin No. 3, note 48 above, p. 21.

${ }^{68}$ Bulletin No. 2, note 48 above, p. 31 .
}

\footnotetext{
${ }^{69}$ Elliot Smith was conscious that this method of selection was suspect. "It may be objected", he wrote, "that skeletons ... 'selected' in any way cannot be regarded as affording reliable data for a statistical study ... But, as the criterion of selection was merely the state of preservation and every part of the cemetery was exploited, our series may be regarded as 'random sampling'." (Bulletin No. 2, note 48 above, p. 32, fn.) He was, of course, completely in error in supposing that he had anything like a random sample, either before or after his selection.
} 
The Study of Human Remains from Nubia

Table 1

Number of Burials recovered from Nubian Cemeteries

\begin{tabular}{|c|c|c|}
\hline $\begin{array}{l}\text { Cemetery } \\
\text { Number }\end{array}$ & Period & $\begin{array}{l}\text { Number of } \\
\text { burials }\end{array}$ \\
\hline 2 & Byzantine & 2,000 \\
\hline 3 & Ptolemaic & 72 \\
\hline 5 & Christian & 510 \\
\hline 7 & Predynastic/Dynastic/Roman & 203 \\
\hline 14 & & 52 \\
\hline 15 & New Empire/Ptolemaic/Roman/Christian & 98 \\
\hline 16 & New Empire & 6 \\
\hline 17 & Early Predynastic & 63 \\
\hline 22 & Old to Middle Empire & 62 \\
\hline 23 & Late Dynastic/Old, Middle and New Empire & 115 \\
\hline 24 & New Empire to Roman & 158 \\
\hline 25 & Roman to Christian & 126 \\
\hline 27 & Roman to Christian & 18 \\
\hline 28 & New Empire & 3 \\
\hline 29 & Old to Middle Empire & 15 \\
\hline 30 & Middle Predynastic/Early Dynastic & 41 \\
\hline 34 & Old to New Empire & 42 \\
\hline 35 & Roman to Christian & 37 \\
\hline 36 & Roman to Christian & 58 \\
\hline 39 & Ptolemaic-Roman and Christian & 83 \\
\hline 40 & $\begin{array}{l}\text { Late Predynastic/Early Dynastic/New Empire/Ptolemaic- } \\
\text { Roman and Christian }\end{array}$ & 258 \\
\hline 41 & $\begin{array}{l}\text { Late Predynastic/Early Dynastic/Old Empire/Middle Empire/ } \\
\text { Ptolemaic-Roman and Christian }\end{array}$ & 108 \\
\hline 42 & Christian & 23 \\
\hline 43 & Middle to Late Predynastic & 68 \\
\hline 44 & Middle to Late Predynastic & 21 \\
\hline 45 & Early Dynastic to Old Empire & 147 \\
\hline 47 & Old to New Empire & 21 \\
\hline 48 & New Empire to Late Roman & 8 \\
\hline Total & & 4,416 \\
\hline
\end{tabular}

dealing are of the greatest interest," wrote Wood Jones, "for their condition gives us an actual picture of the success of ancient surgical methods-or perhaps their neglect of them." A number of bodies were found with splints applied to broken limbs and the material used and the method of application were described in the first Bulletin, in the Report and, by Elliot Smith, in a separate paper to the British Medical Journal. ${ }^{71}$

${ }^{70}$ Report, note 25 above, p. 293.

${ }^{71}$ Bulletin No. 1, note 48 above, pp. 33ff; Report, note 25 above, pp. 293ff; G Elliot Smith,
'The most ancient splints', Br. med. J., 1908, i: $732-4$. 


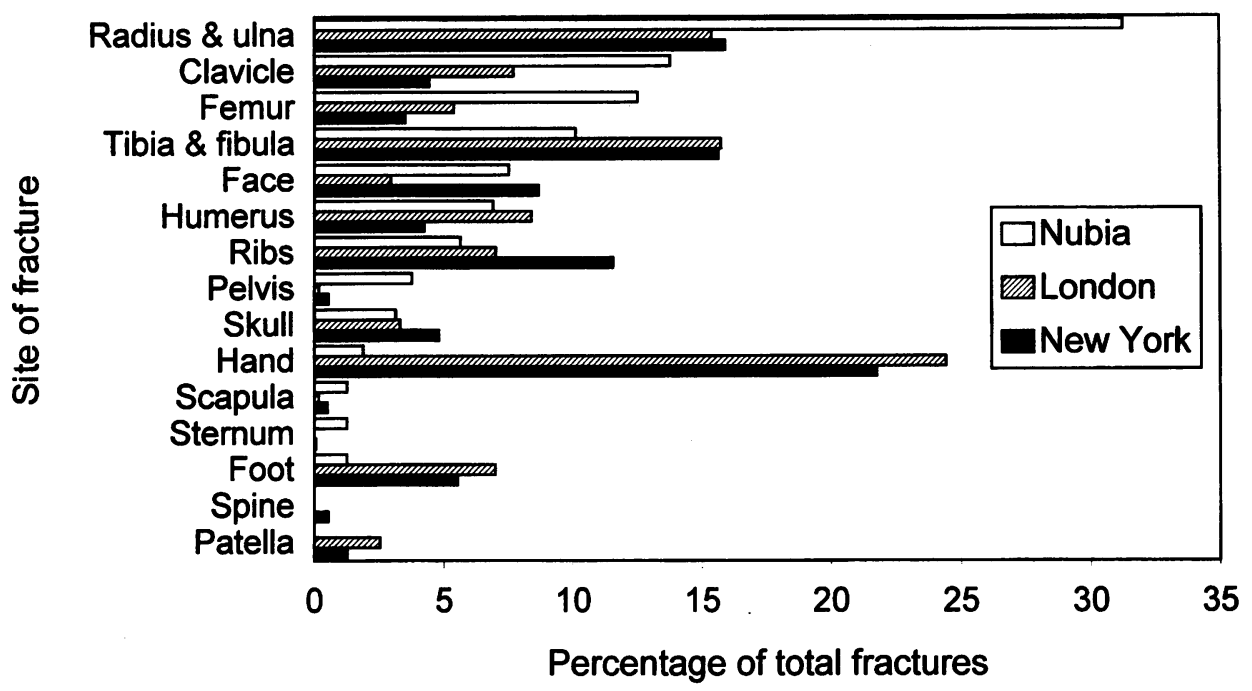

Figure 1: Frederic Wood Jones's analysis of fractures in Nubian skeletons. (Source: G Elliot Smith and F Wood Jones, The archaeological survey of Nubia 1907-1908. Volume 2. Report on the human remains, Cairo, National Printing Department, 1910.)

Wood Jones was interested to see how the distribution of fractures in the Nubian material compared with contemporary patterns and he carried out what was, in effect, a proportional morbidity study, comparing his material with data obtained from London and New York (see Figure 1). He was struck by the obvious differences shown by the analysis, in particular, the great preponderance of fractures of the forearm among the Nubians, which he and Elliot Smith supposed were caused by warding off blows to the head, the so-called parry fractures. This was a valid and useful piece of epidemiology and one which does provide some interesting information about at least one aspect of the ancient Egyptian way of life.

One further aspect of trauma among the Nubians also caught Wood Jones's attention. Two trenches at Shellal had yielded up the bodies of 100 individuals who had been executed by the Romans. The bodies had been bound with cords and one was found with a noose still around his neck. Many of the bodies showed a curious lesion at the base of the skull which was consistent with their having been hanged with some kind of drop. On one side only, the sutures at the base of the skull had been dragged open, and the cranial base had been torn open so that the lateral halves of the skull were disunited. Wood Jones suggested that the men had been hanged with the knot of the rope placed under the ear. He claimed to be able to predict on which side the knot had been placed from the position of the disruption of the sutures. Not all the bodies showed this lesion and none had suffered any damage to the cervical vertebrae. ${ }^{72}$ The disruption to the base of the skull was unlike anything seen in contemporary judicial executions, and, when he was back in

\footnotetext{
${ }^{72} \mathrm{~F}$ Wood Jones, 'The examination of the bodies of 100 men executed in Nubia in Roman

times', Br. med. J., 1908, i; 736-7; Report, note 25 above, pp. 334ff.
} 


\section{The Study of Human Remains from Nubia}

England, Wood Jones extended his interest in the anatomy of hanging. He returned to London in 1909 and took up a post as demonstrator in anatomy at St Thomas's Hospital, where his immediate interest was apparently prompted by the death of a butcher's boy. The boy had put his delivery basket over his head with the handle under his chin and had caught the basket on the top of a doorway, jerking his head back violently and forcefully, dislocating the second cervical vertebra. Wood Jones undertook a post-mortem examination and then, with Frederick Parsons, his head of department, began a series of clandestine experiments dropping cadavers down the lift shaft at the hospital. He found that a sub-aural knot caused disruption of the base of the skull, as at Nubia, but that a knot placed under the chin resulted in a fracture dislocation of the axis and crushing of the spinal cord by the dens. This was at a time when there was a debate in England about the most humane method of execution and Wood Jones presented his evidence towards the debate. ${ }^{73}$

\section{The Notes and Material}

All three men who worked on the Nubian material left Egypt before the excavations were completed. Wood Jones was the first to go, returning to England in May 1909. Elliot Smith outstayed him by only a couple of months, however, for in July he set sail for England to take up the chair of anatomy at the University of Manchester, following the retirement of A H Young through ill health. Derry was alone, trying to deal with the huge amount of material which the workers in the field were bringing up, but in 1910 he too left Cairo, returning to London to take up a post at University College.

It had been intended that at least the more interesting material from the excavations would be examined in greater detail and, in December 1911, Elliot Smith was asked by the Egyptian Government if he would return to "settle up Nubian affairs". ${ }^{74}$ When he arrived in Cairo he found so much work that he was obliged to stay longer than he had anticipated. In addition to the Nubian material, he also completed his examination of the royal mummies and visited Sakkara to examine material which had been excavated from the mastaba tombs of the end of the Second and beginning of the Third Dynasties. Although Dawson states that Elliot Smith was preparing a detailed report of the Nubian material for publication, this never came about, instead he became more deeply enmeshed in his studies of race and diffusionism, to which brief mention will be given later, and a further major account of the Nubian remains never appeared.

\footnotetext{
${ }^{73}$ The butcher's boy story appears in Chiron, 1992, 50. F Wood Jones, 'The ideal lesion produced by judicial hanging', Lancet, 1913, i: 53. See also, G Sternback and A P Sumchai, 'Frederic Wood Jones: the ideal lesion produced by hanging', J. Emerg. Med, 1989, 7: 517-20. In his own account, Wood Jones made no mention of either the butcher's boy or the lift shaft at St Thomas's, rather he attributed his interest in
}

\author{
hanging to his Nubian experiences and his \\ examination of the skull of Pritchard the \\ poisoner, who was the last person to be publicly \\ executed in the United Kingdom in 1865 (F \\ Wood Jones, 'The medico-legal aspect of judicial \\ hanging', Proceedings of the Medico-Legal Society \\ of Victoria, 1931, 1: 1-7). \\ ${ }^{74}$ Dawson (ed.), op. cit., note 9 above, p. 56.
}




\section{H A Waldron}

Some of the material from the Nubian excavations was destined to go to Manchester, and further specimens, about 360 in all, were presented to the RCS. A J E Cave remembers some of the Nubian material being exhibited in galleries in the anatomy department in Manchester during his student days and it did not accompany Elliot Smith to London when he went to take up the chair of anatomy at University College in 1919. Cave worked through the material in Manchester from 1925 to 1929 and remembers that it was in situ at least until 1930, after which time it disappeared, its fate being unrecorded. ${ }^{75}$ When the Manchester medical school moved into new buildings, a quantity of material - 11 boxes in all-was transferred to the Egyptology Department in the Manchester Museum. It was assumed that some of the Nubian material was contained in these boxes but this does not seem to have been the case and it must all now be presumed lost. ${ }^{76}$

The original consignment of material to the RCS was catalogued by S G Shattock, who was then pathological curator, and in 1908 an exhibition was arranged of some 200 fractured and splinted bones. ${ }^{77}$ In 1911, further specimens were sent to the RCS but these were never fully catalogued, although identifying numbers were allocated to them by Shattock. Much of the material was damaged and some lost altogether when the College was bombed in 1941, and in 1953 Wood Jones began the task of restoring what was left; ill health prevented him from completing the work before his death the following year. After this, the material was transferred to the Natural History Museum (NHM) over a number of years and in 1968, specimens which had previously been housed in University College were added to what was already in the NHM. Altogether, 124 specimens are in the NHM and these have been repeatedly examined and have illustrated many works on palaeopathology. ${ }^{78}$

Whatever notes and photographs Elliot Smith kept relating to the Nubian excavations were disposed of after his death by Cave. Writing to W J Perry shortly after Elliot Smith's death, he said:

Lady E.S. wrote to me just before I went north [to get his MD from Manchester]. Wants me to call round this week \& finish going through the boxes of papers the old man left relative to Nubia etc ... I fear the stuff is mostly rubbish, but at least I can take it off her hands, even if I cremate it all later. ${ }^{79}$

The material was not cremated, instead Cave proposed to send what related to Nubia to Reisner in Boston. He wrote to Perry the following week to say:

Saw Lady ES the other day before her departure to Cyprus ... Have got a mass of the old

${ }^{75}$ A J E Cave, personal communication.

${ }^{76}$ The 11 boxes contain only modern teaching material. There are some other boxes in the Museum which contain material from Egyptian contexts, including one mummified head with the calvarium removed to show the dura and what might be some dried brain tissue. None of the material in the Museum could positively be connected with Elliot Smith, however. (T Waldron, 'The putative human remains from Nubia', unpublished MS.)
${ }^{77} \mathrm{~F}$ Wood Jones, 'Some lessons from ancient fractures', Br. med. J., 1908, ii: 455-8.

${ }^{78}$ Theya I Molleson, 'The Nubian pathological collection in the Natural History Museum, London', in Davies and Walker (eds), op. cit., note 8 above, pp. 136-43. Four specimens remain on show in the RCS, including one splinted fracture.

${ }^{79} 12$ July 1927 . University College Library, ADD MS 269, later referred to as UCL. 


\section{The Study of Human Remains from Nubia}

man's stuff[:] photos, old anatomical drawings \&c. \& c.- -all incomplete, dilapidated \& dirty and all referred to published stuff. If possible, I propose to have a selection of his original brain drawings bound in a volume, so that Lady ES can keep them as a memento. A number of photos of Nubian Survey plus photos taken in the field-are going to Reisner-but many of them have already been published. ${ }^{80}$

There is little prospect of any substantial amount of the notes which Elliot Smith, Wood Jones or Derry wrote in the field being recovered and thus a valuable source of information seems irrevocably lost, a source which might have permitted some reworking of the original data and perhaps also allowed some studies of the prevalence of disease in ancient Egypt to be made.

\section{After Nubia}

Of the three men involved in the examination of the Nubian remains, only Derry returned to work in Egypt. After a spell at University College, he was appointed professor of anatomy-Elliot Smith's old chair-in 1919 and he stayed in Egypt until he was expelled during the political upheavals in 1952. Derry's interests did not include palaeopathology to any great extent, although he did continue to examine human remains recovered from various sites in Egypt, including the mummy of Tuthankamun, the work for which he will probably be longest remembered. ${ }^{81} \mathrm{He}$ also engaged in a debate with Elliot Smith about the prevalence of dental disease in Egypt and over the years his regard for Elliot Smith seems to have been lost, or at least greatly to have diminished. In a letter to Perry of 19 July 1937, Cave wrote: "Did I tell you I met Derry at Oxford. Seems most uninspiring \& very definitely anti-G.E.S. We were not amused." ${ }^{\prime 2}$ The reasons for Derry becoming so anti-G.E.S. cannot be traced, but he was not alone in becoming alienated from his former boss.

After Nubia, Wood Jones embarked on a very peripatetic career. From Cairo he returned to London where it was hoped that he might succeed Arthur Keith at the London Hospital, the latter having been appointed to take charge of the Museum at the RCS. Instead, he went to St Thomas's Hospital as a demonstrator in anatomy but joined Elliot Smith in Manchester as a lecturer for a brief period before going once more to London to become first professor of anatomy at the Women's Medical School. After the First World War he was successively professor of anatomy in Adelaide, Hawaii, and Melbourne, and then returned full circle to Manchester to

${ }^{80}$ UCL, 19 July 1937. A few weeks later (11 August 1937) Cave wrote again to Perry to say that Elliot Smith's correspondence had been sent to Dawson by Elliot Smith's son, Arthur, so that Dawson could use it in the preparation of his book (note 9 above). I have been unable to find out exactly what material was sent to Reisner but I understand that approximately five years ago, the material was sent from Boston to Cairo ( $R$ Walker, personal communication).

${ }^{81}$ D E Derry, 'Report upon the examination of Tut-Ankh-Amen's mummy', in H Carter, The tomb of Tut-Ankh-Amen, London, Cassell,
1927, pp. 143-61. Derry left a collection of material which has recently been catalogued (The Egyptian Society for Bioanthropological Sciences, The Derry-Batrawi Collection, Kasr el Einy Faculty of Medicine, Cairo, Egypt, Montillier, Bioanthropological Foundation Ltd., n.d.). In the 1920 s and 1930 s, Derry worked very closely with H E Winlock, examining much human material for him. Details of this collaboration can be found in the UCL papers and in papers held in the Metropolitan Museum of Art, New York.

${ }^{82} \mathrm{UCL}$, note 79 above. 


\section{H A Waldron}

take Elliot Smith's old chair until he retired, when he was appointed first professor of anatomy at the RCS in 1945.

Elliot Smith occupied the chair of anatomy in Manchester until 1919 and then went to University College, London. He retained a keen interest in the anthropological and cultural aspects of ancient Egypt and for a number of years was the chairman of a panel appointed by the British Association for the Advancement of Science to investigate the racial characteristics of the ancient Egyptians. ${ }^{83}$ His work in Egypt led him to develop a theory about the diffusion of Egyptian culture and habits around the world - especially megalith building and mummification - which he expounded in The ancient Egyptians, first published in $1911 .^{84}$ In this aspect of his work, Elliot Smith was assisted by William Perry, who worked with him in Manchester and at University College. W H R Rivers was also persuaded by his arguments and together they constituted a triumvirate whose views came to be accepted "as a litany of futility by generations of students". 85

Elliot Smith's diffusionist hypothesis met with very great opposition, as he acknowledged in the preface to the second edition published in 1923. Rivers had apparently told him that "my first incursion into ethnology was a flagrant defiance of all the current doctrines of that branch of study, and would draw down upon my head the most bitter opposition-a prediction that was amply fulfilled." ${ }^{\prime 86}$ There is a copy of the second edition in the library in University College which has pencilled notes by Flinders Petrie. "No", appears in his hand on several pages; "no evidence", "no evidence of this", "no such thing", "what a romance!!", and on the first page

\footnotetext{
${ }^{83}$ See, 'The people of Egypt', Report of the eighty-second meeting of the British Association for the Advancement of Science, London, John Murray, 1911, pp. 727-8; 'Physical characteristics of the ancient Egyptians', Report of the eightyfourth meeting of the BAAS 1914, London, John Murray, 1915, pp. 212-28; 'Physical characteristics of the ancient Egyptians', Report of the eighty-fifth meeting of the BAAS,

Manchester, 1915, London, John Murray, 1916, pp. 189-93. His work on race, and also that of Arthur Keith, is described further in N Stepan, The idea of race in science: Great Britain, 1800-1960, London, Macmillan, 1982, especially pp. 92-3 and 108-9.

${ }^{84} \mathrm{G}$ Elliot Smith, The ancient Egyptians and their influence upon the civilization of Europe, London, Harper \& Brothers, 1911.

${ }^{85}$ R Slobodin, W.H.R. Rivers, Stroud, Sutton Publishing, 1997, p. 73. In addition to being colleagues at St John's College, Elliot Smith and Rivers served together during the First World War at Maghull Military Hospital. Elliot Smith was appointed Rivers' literary executor after his death and published a number of his works with a preface or introduction, and "it is certainly
}

possible that they were edited in the direction of [the] diffusionist argument" (Slobodin, op. cit., p. 57 , fn 253). Slobodin's point is probably nowhere better exemplified than in the inclusion of Rivers' essay on 'The aims of ethnology' in Psychology and politics: and other essays (London, Kegan Paul, Trench, Trubner, 1923). The essay is a eulogistic account of Elliot Smith's work and is accompanied by a note by Elliot Smith himself in which he says "The importance of the article by Dr Rivers is that it sketches the history of a movement to destroy the fallacies of supposed independent evolutions of customs and belief by proving than in ancient times, as at present, knowledge and men's interpretation of their experience were diffused abroad throughout the world" ("Ethnology and psychology. A note on "The aims of ethnology", op. cit., pp. 141-5). In other words, Elliot Smith is praising Rivers' laudatory account of his own work. Perry's account of Elliot Smith's anthropological work appears in 'Anthropologist and ethnologist', in Dawson, op. cit., note 9 above, pp. 205-15.

${ }^{86} \mathrm{G}$ Elliot Smith, The ancient Egyptians and the origins of civilization, 2nd ed., London, Harper \& Brothers, 1923, p. vi. 


\section{The Study of Human Remains from Nubia}

of the preface, "The asserted facts are largely untrue \& the vague statements unsupported". ${ }^{87}$

At the time the second edition of The ancient Egyptians appeared, Elliot Smith and Petrie were colleagues at University College but they were barely on speaking terms. Margaret Murray refers to their feud and to her concern about the seating arrangements when the Board of Studies in Anthropology-of which she was secretary - was convened. If she could get each man to sit where the other could not see him, then the meeting would go smoothly, otherwise "there were sarcastic remarks and bitter retorts all the time" ${ }^{88}$ According to Murray, the feud started when Elliot Smith attacked Petrie's suggestion that the skeletons of Naqada showed evidence of cannibalism. Petrie offered to show Elliot Smith all his evidence only to be rebuffed in a short letter which apparently stated, "I don't care what evidence you show me, I shall not believe it". This-as Margaret Murray says-closed the door to any kind of amicable discussion. ${ }^{89}$

While he was in Manchester, Elliot Smith also fell out with Arthur Keith and, partly as a consequence of this, partly for other reasons, he also alienated Wood Jones. The row with Keith was based on their differences about the validity of Arthur Smith Woodward's reconstruction of the Piltdown skull. Keith was unconvinced by the reconstruction and invited Elliot Smith and others to the RCS to discuss it. Elliot Smith was not persuaded by Keith's arguments and the discussions were continued at a meeting of the International Congress of Medicine in August (1913). Various anatomical luminaries gathered again at the RCS and Keith once more voiced his reservations and also aired them publicly in the columns of The Times. The controversy then spilled over into the pages of Nature where Elliot Smith attacked Keith's interpretation of the anatomy of the skull..$^{90}$ This was followed by a meeting at the Royal Society at which Elliot Smith read a paper and Keith pointed out "the glaring errors in the reconstructed brain-cast he exhibited to the meeting". At the end of the meeting it happened that Elliot Smith and Keith left side by side. "I shall never forget the angry look he gave me. Such was the end of a long friendship," Keith wrote later in his autobiography. ${ }^{91}$

\footnotetext{
${ }^{87}$ Glyn Daniel makes reference to Petrie's comments in his rebuttal of the diffusionist hypothesis. See 'Elliot Smith, Egypt and diffusionism', in Zuckerman, op. cit., note 9 above, pp. 407-47.

${ }^{88} \mathrm{M}$ Murray, My first hundred years, London, Kimber, 1963, p. 165.

${ }^{89}$ Ibid., p. 113. Murray states that Elliot Smith's attack on Petrie was contained in an article in Nature, but I have been unable to locate it. The original account of Naqada appeared in 1896, the year that Elliot Smith arrived in England and it seems unlikely that he would have been asked to review it as a virtual unknown in this country and the volumes of Nature for the last years of the nineteenth century contain nothing by him on this subject. It is possible that Murray's memory was at fault and that the
}

contentious article appeared elsewhere.

${ }^{90} \mathrm{G}$ Elliot Smith, 'The Piltdown skull', Nature, 1913, 92: 131; A Keith, 'The Piltdown skull and brain cast', ibid., 197-9; G Elliot Smith, 'The Piltdown skull and brain cast', ibid., 267-8; A Keith, 'The Piltdown skull and brain cast', ibid., p. 292; G Elliot Smith, 'The Piltdown skull and brain cast', ibid., 318-19; A Keith, 'The Piltdown skull and brain cast', ibid., 345-6.

${ }^{91}$ Keith, op. cit., note 13 above, p. 327. It is interesting that both Elliot Smith and Keith have been accused of perpetrating the Piltdown fraud. Elliot Smith was implicated in The Piltdown men (R Millar, London, Gollancz, 1972) and Keith more recently in Piltdown: a scientific forgery (F Spencer, London, Natural History Museum Publications, 1990). The idea that either man would have done such a thing is risible. 


\section{H A Waldron}

There is no doubt that Wood Jones supported his old friend and mentor in his troubles with Elliot Smith but he too fell out with him, over the phylogeny of Tarsius. While they were both in Manchester, Elliot Smith had been given some specimens of Tarsius by a friend, Charles Hose, who was working in Borneo, and he asked Wood Jones to study them. This he did, and included some of the results of this study in the published form of the Arris and Gale Lecture which he gave at the RCS. In the book, he put forward ideas which Elliot Smith considered were his own, that is to say, that the Prosimii should be included among the primates, but he also amplified with modifications of his own. Two years later, in 1918, Wood Jones published a small booklet in which he put forward the idea that man had evolved from a Tarsius-like animal, rather than through the conventionally held route. In this pamphlet Wood Jones

Emancipated himself ... from any influence my views may previously have had [wrote Elliot Smith], and issued his remarkable speculations ... in which he attempted to exclude all the Apes and Monkeys from Man's ancestry and to derive the Human Family directly from a Tarsius-like animal. ${ }^{92}$

Wood Jones's 1918 pamphlet was the published form of a lecture given at King's College, London, in February 1918 and both the lecture and the publication "received a large share of adverse criticism, and one outcome ... was the very remarkable discussion ... held at the Zoological Society in the following year" ${ }^{93}$ As Zuckerman relates in his account of the meeting, "many of the 'heavy weights' of the period participated". Elliot Smith spoke after Smith Woodward and disparaged Wood Jones's notion, although in the written record of the meeting he does not appear to have alluded to Wood Jones by name. Even Zuckerman, who was clearly Elliot Smith's man, thought that he had been "unnecessarily scathing in his remarks". ${ }^{94}$ Wood Jones himself was the fourth speaker and was somewhat reticent in advancing his views, so much so that during his summing up, E W MacBride noted that he had "rather shrunk [from the position] to which he had liberally committed himself in recent books published by him". ${ }^{95}$ In fact, Wood Jones was not trying to suggest much more than that Tarsius was a true primate and that Tarsius and man shared

\footnotetext{
${ }^{92} \mathrm{~F}$ Wood Jones, Arboreal man, London, Edward Arnold, 1916; The problem of man's ancestry, London, SPCK, 1918; G Elliot Smith, The evolution of man, London, Oxford University Press, Henry Milford, 1927, p. iv.

${ }^{93} \mathrm{~F}$ Wood Jones, Man's place among the mammals, London, Edward Arnold, 1929, pp. v-vi.

${ }^{94}$ Zuckerman (ed.), op. cit., note 9 above, pp. 3-21. Zuckerman, of course, supported Elliot Smith in his confrontations with Keith. Although both men were kind to him when he arrived in England from South Africa, Zuckerman thought that Keith's "scientific qualities ... were in inverse proportion to his widespread influence and charm" and "the diagnostic procedures he
}

employed in matters osteological savoured more of divine inspiration than of normally accepted scientific method". Zuckerman, I suspect, shared many of Elliot Smith's characteristics and was himself not averse to controversy as his celebrated feud with Le Gros Clark over "root 2" shows. Zuckerman describes this affair, which involved several major figures, in the second volume of his autobiography, Monkeys, men and missiles. An autobiography 1946-88, London, Collins, 1988 , pp. $25-6$; it is a rather one-sided account.

${ }^{95}$ For the report of this meeting, see A Smith Woodward, et al., 'Discussion on the zoological affinities of Tarsius', Proceedings of the Zoological Society of London, 1919, pp. 465-98. 


\section{The Study of Human Remains from Nubia}

some primitive characteristics which the apes and monkeys had lost; a view now considered orthodox. ${ }^{96}$

In the following years, Elliot Smith maintained his hostility both to Wood Jones and to Keith. "I'm seeing very little of E.S.," Keith wrote to Wood Jones in 1928. "he becomes ishmaelitic more \& more \& rather harshly critical of his best \& oldest friends ... But all the same he has a nose for what way the truth lies but greedy for all the Kudos available". ${ }^{97}$ In the following year, Wood Jones wrote to Keith from Hawaii, discussing whether he should apply for the chair in Edinburgh.

I would put in for Edinburgh so that I could work for my own people and under my own flag-but, as you know very well, there would be great opposition to me-a very great deal from Gower Street. I never can make out the mentality of the trio-Elliot Smith, Hill and Watson ... Watson, I know dislikes me very much, and E.S.-is E.S. ${ }^{98}$

Later in 1929, Elliot Smith wrote to Keith following the publication of Wood Jones's Man's place among the mammals in which he returned to his view on human evolution.

J.P. Hill yesterday gave me a message from you with regard to writing a notice of Wood Jones' lapse for the Journal [of Anatomy]. I would much prefer not to have anything to do with it as I think that any notice of the book from you or me would simply be pandering to his craving for notoriety which is having a disastrous effect on his scientific work ... Every review that I have written of his work has been marked by the limits of indulgence, and I do not now want to begin writing in the way his recent work deserves. ${ }^{99}$

Wood Jones had anticipated the worst, as shown by a letter to Keith from Honolulu:

I see "Mans [sic] Place" is out-and I await some abuse in the form of reviews. I don't anticipate its popularity with everyone, but that does not matter-if Elliot Smith had refrained from his nasty methods with me I would not have been at the trouble to hunt out his own inconsistencies in his own special field. ${ }^{100}$

The Journal of Anatomy did carry an unsigned review of the book which was reasonably balanced although the reviewer could not resist remarking that Wood Jones "rather tends to prejudice the reader against a fair and calm enquiry into the tenability of his conclusions by some unhappy attacks on authorities of recognised standing, and by including in his arguments data, the accuracy of which is open to question or, in some cases, which are definitely erroneous". ${ }^{101}$ There seems little doubt that Elliot Smith was one of those "authorities of recognised standing" and it is possible that he was actually the author of the piece.

Wood Jones and Keith continued to discuss Elliot Smith in their letters. "You are right \& you are wrong about E.S.", wrote Keith, in response to a comment that Elliot Smith had failed to have pupils. "He has been my greatest disappointment: we could have done so much pulling together ... He suffers from two very bad and

\footnotetext{
${ }^{96}$ For further details of this controversy, see P J Bowler, Theories of human evolution. A century of debate, 1844-1944, Baltimore, Johns Hopkins University Press, 1986, especially ch. 5 (pp. 112-30).

${ }^{97}$ RCS, 11 December 1928.
}

\author{
${ }^{98}$ RCS, 3 January 1929. \\ ${ }^{99}$ RCS, 9 November 1929. \\ ${ }^{100}$ RCS, 24 November 1929. \\ 101 'Man's place among the mammals', $J$. \\ Anat., 1930, 64: 531-4.
}




\section{H A Waldron}

incurable disorders: Jealousy and Egomania: if he had put his subject $1^{\text {st }}$ and himself second all would have been well." 102

Elliot Smith's last years were marred by personal misfortune. In 1931 his wife suffered from a prolonged bout of broncho-pneumonia and in 1932 he had a stroke from which he never fully recovered. According to Zuckerman, Elliot Smith diagnosed the onset of his stroke. After work one evening he asked Zuckerman if he would accompany him home. While waiting for the bus to take them to Camden Town, Elliot Smith wiped the side of his nose and said to Zuckerman, "I am wondering which of my lenticulo-striate vessels are leaking. All day I have felt as though I've a cold on the right side of my nose, and there's been a slight tingling in my fingers. I wonder how serious a stroke it's going to be". ${ }^{103}$ Although he recovered sufficiently to return to work in 1934, he never regained his previous vigour. In 1936 his youngest son died in an accident and shortly afterwards, his wife had a serious accident at home which confined her to hospital. To add to his problems, the lease on his house lapsed and he was forced to vacate it immediately as the landlord wanted to demolish it to make way for another development. With his wife in hospital, Elliot Smith entered a nursing home in Sidcup where he remained until a few days before his death on New Year's day, 1937.

Towards the end of September, 1936, Arthur Keith wrote again to Wood Jones:

E.S. is in a hospital in Sidcup: his wife is in U.C. Hospital suffering from a bad burn. I would go to see Elliot-J.P. Hill thinks I ought. But deep down in my heart I feel a repulsion to such an interview. We differ so radically that we could only exchange nothings. He alienated you from interests \& me too \& I do believe that it all has sprung from an uncontrolled and uncontrollable jealousy. ${ }^{104}$

Wood Jones summed up his own feelings in a reply from Melbourne in November.

I am sincerely sorry for poor old E.S. he seems to have come to a very sad old age. His wife, his son-everything. I fancy that at bottom all his troubles are the outcome of the fact that he is an Australian \& that he married an Australian wife... . He ... had a good brain, great charm, and a lot of Huxley's characteristics. But-here you can laugh at a man named Jones, born in Hackney - he was at bottom, like so many Australians, lacking in those things, loyalty, sincerity, altruism - and the hundreds of other unspoken things, that constitute the basis of (hated word) a gentleman.

I would have been very loyal to E.S., for I learned to be very fond of him in Nubia-where he was at his best ... in camp he was the finest companion one could wish for. But social ambitions, mainly due to his wife-intense jealously of his fellows-intolerance-and a little devious streak, not altogether nice, made him hard to serve as a loved master. Still I shall always owe him a debt for the days in camp in Nubia-and I am very sorry his old age is being a sad one. ${ }^{105}$

Wood Jones wrote three obituaries for Elliot Smith and none give any indication of the extent to which relations between them had soured. The nearest he came to a critical comment was in the obituary written for the Australian National Review:

\footnotetext{
$\begin{array}{ll}{ }^{102} \text { RCS, } 31 \text { March } 1931 . & { }^{104} \text { RCS, } 20 \text { September } 1936 . \\ { }^{103} \text { Zuckerman (ed.), op. cit., note } 9 \text { above, p. } & { }^{105} \text { RCS, } 9 \text { November } 1936 .\end{array}$ 19.
} 


\section{The Study of Human Remains from Nubia}

He was a genial man, charming and courteous in debate, so long as the debate was carried out by the spoken word. But once his pen was in his hand his gentleness forsook him, and although his old master (Professor Wilson) has described his method of written criticism as "somewhat trenchant," there are those among his fellow anatomists who would prefer the use of the word "pungent". The pen is doubtless mightier than the sword, but, all too often, Elliot Smith employed it as a dagger. ${ }^{106}$

He was somewhat more frank with Arthur Keith. "As for biographical notices of E.S., I have done 3, and have tried very hard to bring out the very nice human aspect that he undoubtedly had-when he was not a controversialist: then he was truly poisonous. In the end he came back to me and wrote me some nice letters before he died." 107

\section{Conclusion}

The principals in this history lived at a time when anatomy was held in great esteem and some anatomists were household names. This was largely to do with the pre-occupation by both the profession and the public with fossils and the spectacular discoveries which were being made on the Continent and in South Africa, for example. The other obsession with anatomists was the question of race and racial characteristics and it was, of course, this which was the driving force behind Elliot Smith's Egyptian studies. Palaeopathology was at best only an incidental interest to any of those engaged in the Nubian excavations and, as a discipline in its own right, it can scarcely be said to have benefited materially at all from the work which Elliot Smith, Wood Jones and Derry undertook. What advances took place in this field were largely down to Ruffer, but his death by drowning at sea in 1917 was a catastrophic blow to the subject. Some important work was being undertaken in the United States, but only until about the early 1930s, when the subject entered the doldrums there also, being revived only in the late sixties. ${ }^{108}$ In Great Britain, palaeopathology was revived after the Second World War by a small number of individuals, of whom Calvin Wells was probably the foremost in marketing it to the general public. ${ }^{109}$ The examination of the human remains from the Nubian excavations was undertaken under the most trying conditions, at breathless speed, and a vast amount of data was accumulated, most of which is now either lost or in a form in which it is virtually useless to contemporary workers. On a personal note, the three principals drew apart and at least two, Elliot Smith and Wood Jones, engaged in acrimony which saw them, if not enemies, then at least estranged. Elliot Smith's

\footnotetext{
${ }^{106}$ Wood Jones, op. cit., note 9 above, p. 8 .

${ }^{107}$ RCS, 24 March 1938.

${ }^{108} \mathrm{~S}$ Jarcho, 'The development and present condition of human palaeopathology in the United States', in Jarcho (ed.), op. cit., note 5 above, pp. 3-30.
}

\footnotetext{
${ }^{109}$ Wells' book, Bones, bodies and disease (London, Thames \& Hudson, 1964), for example, was influential among archaeologists and the general public alike. From 1950 to 1960 he was cited far more often than any other British palaeopathologist ( $T$ Waldron, unpublished data).
} 


\section{H A Waldron}

own racial theories no longer have credence and his diffusionism was rejected even in his own lifetime. A study of this episode must conclude-however reluctantly-that far from contributing importantly to any area of study, the whole endeavour was "a field from which success is banished". 110

${ }^{110} \mathrm{R}$ L Stevenson, 'A Christmas sermon', in Across the plains, London, Chatto \& Windus, 1892. 